\title{
Improving the Competency to Construct Test Items for Class VI Teachers Through Workshop
}

\author{
Langgeng Basuki ${ }^{1}$, Subuh Anggoro ${ }^{2}$ \\ \{ langgengdewi@gmail.com ${ }^{1}, \underline{\text { subuhanggoro@ump.ac.id }}$ \} \\ ${ }^{1,2}$ Magister of Basic Education, Universitas Muhammadiyah Purwokerto \\ ${ }^{1}$ Supervisor of Elementary School Korwilcam Dindik Somagede
}

\begin{abstract}
The success of the learning activities that took place in school certainly cannot be separated from the competence factor possessed by a teacher. The purpose of this action research was to determine the improvement in the competency of class VI teachers to construct test items at Dabin III Tambak District through a workshop. The research was carried out to grade VI teachers at Dabin III Tambak Distrik, Banyumas Regency, namely to 9 teachers The School Action Research Report was submitted to assess the credit point from the elements of professional development. While, by comparing the score gained to the initial conditions, cycle I to cycle II at the average score of 59 in pre-cycle, 69in cycle I and increased again to 81 in cycle II. Based on such findings, a conclusion can be drawn as follows: The implementation of workshops can improve the competency of class VI teachers to construct test items at their schools,namely Dabin III, Tambak District, Banyumas Regency
\end{abstract}

Keywords: teachers competency, workshop activities, test items, elementary school

\section{Introduction}

Teachers must have the competency to assess the students' learning outcomes that refers to educational assessment standards Assessment students' learning outcomes is carried out using a test instrument [1]. A qualified test instrument can help the students to improve their learning and provide accurate information on the students' competencies achievement, thereby able to identify the students who have reached the competence and those not yet [2].

Assessment of student learning outcomes is the process of analysing data to determine whether or not students have achieved their learning objectives. Educators' evaluations have the characteristics of complete, authentic, continuous learning, are based on reference criteria/benchmarks, and use a combination of techniques and assessment instruments to monitor students' learning processes and progress, as well as to increase the effectiveness of learning activities [3].

Based on the author's observations of the schools under the author's supervision as the Supervisor of Elementary Schools in the Supervised Territory (Dabin) III Tambak District Education Unit, the teachers' competency to construct test instruments namely, the test items is still low. The observation findings to the preparation of the test items in the daily test for class VI teachers indicated that the teachers at schools in the territory under the author's supervision still failed to comply with the procedure or the best practice of constructing test items. The test items were arranged and assembled and then used for the test, without preceded with the preparation of test items matrix, test items cards, qualitative analysis, and quantitative analysis. 
By such condition, it is highly necessary to improve the competency of $6^{\text {th }}$ grade teachers in Dabin III of the Tambak District Education Unit to construct test items. They still failed to comply with the procedure in constructing the test items, possibly due to the absence of academic coaching on constructing test items classically or individually that should have been carried out by the author as the Supervisor.

The coaching already carried out was general coaching on work discipline and completeness of teacher administration. The low competency of the sixth-grade teachers in Dabin III to construct the test items encouraged the author to research terms of school action research, with the purpose to significantly improve the competency of the sixth-grade teachers in Dabin III to construct the test items. The improved competency to construct test items can improve student learning achievement. To this end, it is necessary to carry out a program to improve the teachers' competency to construct test items [4]

The success of the learning activities that took place in school certainly cannot be separated from the competence factor possessed by a teacher. Competence according to Rahmawati and Daryanto is abilities and skills in the form of knowledge, skills, and abilities possessed by individuals so that they can perform cognitive, affective, and good psychomotor [5]. To be a professional teacher, they requires several criteria, namely having a strong commitment to high on the task being done based on competency standards for graduate students, responsible with a given workload, think systematically about what to do, able to master the material, able to organize, be independent in designing the learning process, must be able to carry out research activities, be able to write scientific works and teachers who are active in professional organizations [5].

A competent teacher is determined by her competency to carry out her duties and responsibilities as an educator. Teachers who can carry out their duties properly are called professional teachers, namely teachers who have the competency, by the teacher competency standards, namely psychological competence, personal competence, social competence, and professional competence. Pedagogic competence is one of the competencies that subject teachers must master. It consists of several core competencies of teachers.

The construction of a test item is a focal step in producing a good test measuring instrument [3]. It is the elaboration of indicators of the type and level of behavior to be measured into questions which the characteristics in accordance with the matrix [6]. The teachers are able to construct the test items properly if they have a good understanding of the assessment techniques and test development procedures. Test items will have high quality if valid and reliable. In the opinion of Nana Sudjana, the assessment is said to be good if the question has or meets two criteria, namely validity and reliability [7].

Meanwhile, Arikunto states a good test is if it meets the test requirements, namely validity, reliability, objectivity, practicality, and economics [8]. (1) Validity is the validity or validity of a question, the validity of the question can be seen from whether or not the question can be assessed in an assessment. (2) Reliability is the similarity of test results if tested if the test is carried out at different times. (3) Objectivity means that there is no personal element of the appraiser in giving value. (4) Workability is a test that is easy to run, equipped with instructions that can be done by everyone. (5) Economical means that in its implementation the test does not require expensive costs and a short time

Workshop or training means "Loka Karya" in Indonesian. The workshop is "learning by doing", which is guided by the trainer and in the activities, there are practices taught by the trainer. A workshop is very good for activities that aim to master a certain topic since it is outputoriented [10] (Uluyol and Şahin, 2016)). The workshop held at Dabin III Tambak District was aimed at improving the teachers' competency to construct test items, thereby the object was the 
teacher and the supervisory trainer, namely the researcher, and the output was valid and reliable test items. The low competency to construct test items can be overcome by academic coaching through workshops in the two schools assisting. Academic coaching to improve the teachers' competency of grade VI teachers in Dabin III to construct test items was carried out by the author through a workshop, continued with assistance in their respective schools.

\section{Method}

This study uses a Classroom Action Research (CAR) model Kemmis \& Mc. Taggart. There are four stages in the model in The cycle is planning, action, observation (observation) and reflection spiral shape as shown on Figure 1.

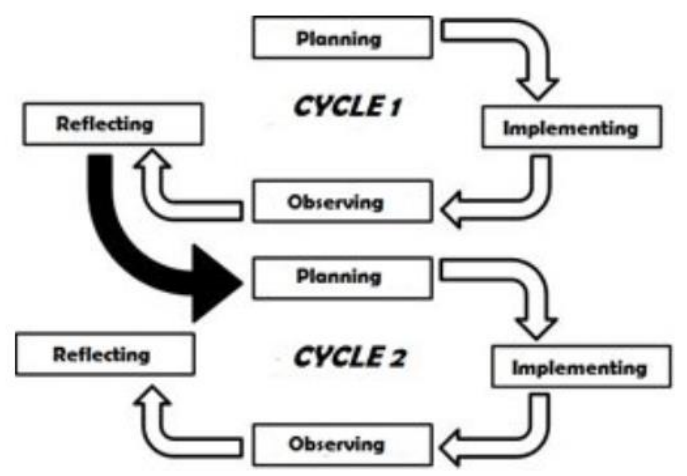

Figure 1. The cycle of CAR (Suharsimi, 2015)

This school action research took place for six (6) months. It was conducted starting from the writing of a proposal to the writing of research report. The research was carried out to 9 teachers grade VI teachers at Dabin III Tambak Distrik, Banyumas Regency. This research was conducted to identify the professional level of class VI teachers at Dabin III Tambak District in constructing the test items. This school action research was carried out with the purpose to improve the professionalism of class VI teachers at Dabin III Tambak District, thereby eventually able to improve the achievement of students in SDs in the Dabin III of Tambak District.

The school action research technique adopted was by evaluating the initial conditions by assessing the test items constructed by grade VI teachers, conducting problem-solving discussions, and continued with the implementation of the action, namely a workshop and ended with the evaluation of the results. The data were obtained by conducting pre-assessment and post assessment to the test items by using the test items construction assessment instrument.The results of the assessment of the test items are recapitulated and its average was found out to identify whether or not there is improvement in the competency to construct the test items for grade VI teachers at Dabin III Tambak District.In addition to the test item assessment instrument, data were obtained by observation, interviews and notes made by the author during the research.

The research was conducted in 2 cycles consisting of 4 stages, namely planning, action implementation, observation, and reflection. 


\section{Result and Discussion}

\section{Before Workshop Condition}

This school action research takes place at Dabin III UPK Tambak in Banyumas Regency, with the subject of class VI teachers. The author conducted additional observations to determine the cause of the teacher's poor ability to compile items. One of the reasons for teachers' low ability to compile items is the lack of coaching for teachers on item preparation. The observation resulted that the ability of $6^{\text {th }}$ grade teachers at Dabin III UPK Tambak, Banyumas Regency to compose items is still low.

Following the collection of data on teachers' ability to compile items, the author encouraged the authors to conduct school action research with the goal of improving the ability of 6th grade teachers to create items. This research was conducted in collaboration with the principals of seven elementary schools in Dabin III UPK Tambak, Banyumas Regency. The method employed is a workshop with two cycles, each of which consists of three meetings. In these schools, the workshop method is expected to solve problems.

\section{Workshop of Construct Items}

The first step in planning is to identify the schools that would be the focus of school action research. The author's target school, Dabin III UPK Tambak Banyumas Regency, was the sixth grade teacher in nine elementary schools. In planning activities, the author developed indicators of the workshop's success in improving the ability of class VI teachers to prepare questions. The author sets a minimum value of 65 as an indicator for the success of implementing this action, which means that this action is declared successful if the teacher's average score reaches a minimum value of 65 .

The next planning activity is the formulation of action steps, which begins with outreach to class VI teachers and school principals at Dabin III UPK Tambak, Banyumas Regency, about the research to be conducted, research objectives, and the use of workshops as problem solving solutions. The due to the ability the identification of data collection methods that will be used in research during planning activities. The author's method is qualitative collection of data via assessment with instruments, observations, and interviews with teachers as research targets and school principals.

The item assessment instruments, qualitative analysis instruments, and quantitative analysis items were obtained from a variety of sources, including the Ministry of National Education's item preparation guidelines, the internet, and other relevant sources. Notes have been prepared to record important information from the workshop activities. The interview materials were created in order to collect accurate data in order to determine the success of the school action research and to make the assessment and preparation of complete and accurate reports easier.

A workshop on the preparation of questions was held with the author's resource persons during the implementation of the first cycle of the first meeting, and the participants were all elementary school teachers from Dabin III UPK Tambak, Banyumas Regency. The workshop was held at SD Negeri Watuagung, and 54 teachers attended. 

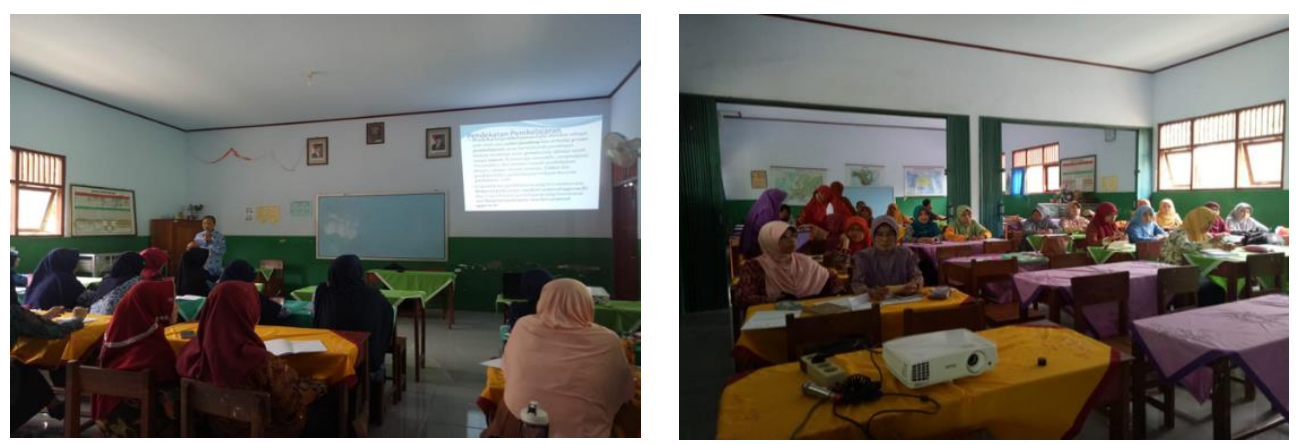

Figure 1. Workshop of Costruct Test Items

The first cycle meeting activity is to collect a matrix of questions, question cards, and questions for school exam practice questions. The second meeting implementation were used to analyze the results of questions. These questions were tested, and the results will be analyzed at cycle third meeting. This activity took place at SDN Watuagung UPK Tambak in Banyumas Regency, were attended 9 teachers of $6^{\text {th }}$ grade.

The results of the assessment of sixth grade teachers' ability to prepare items at Dabin III UPK Tambak, Banyumas Regency in the first cycle did not meet the requirements. Some teachers proceed to have a misunderstanding of quantitative analysis. So, this research activity was continued in the second cycle by taking the results of reflection into record.
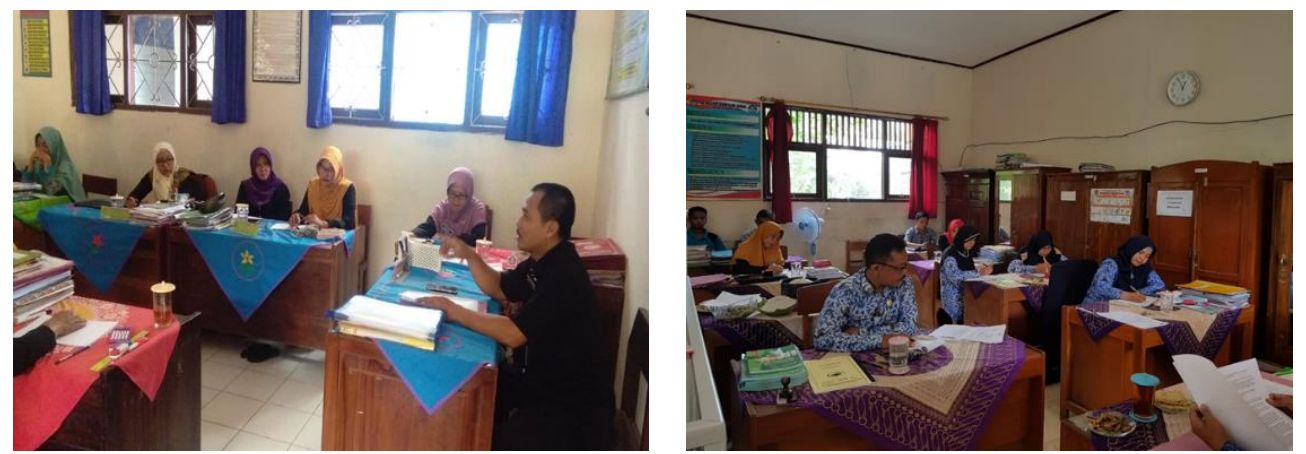

Figure 2. The Process of Contruct Test Item Supervising in First Cycle
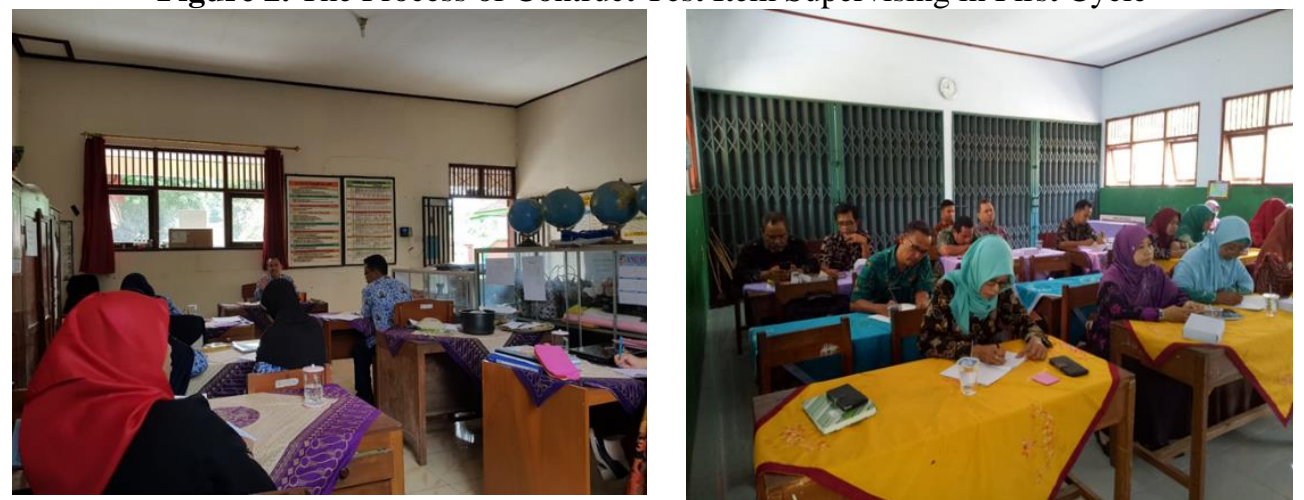

Figure 3. The Process of Contruct Item Supervising in Second Cycle 
The results of this study can be seen from the data obtained in the pre-cycle, cycle I, and cycle II. The target of the results of this school action research is a minimum score of 65 , the average value of the ability to compose questions before conducting research in Dabin III, Tambak District, Banyumas Regency is 59.

Table 1. The Comparison of Data on Ability to Compose Items in Initial Conditions, Cycle I and Cycle II

\begin{tabular}{|c|c|c|c|}
\hline NAME OF TEACHER & PRE CYCLE & CYCLE I & CYCLE II \\
\hline SM & 54,1 & 64 & 77 \\
\hline Mt & 57,6 & 68 & 80 \\
\hline $\mathrm{IM}$ & 60 & 71 & 82 \\
\hline Sst & 59 & 72 & 79 \\
\hline NM & 64 & 69 & 81 \\
\hline ANE & 60 & 74,1 & 86 \\
\hline NA & 57 & 60 & 78 \\
\hline $\mathrm{TM}$ & 59 & 66 & 79 \\
\hline RDS & 60 & 75,3 & 85 \\
\hline Average & 59 & 69 & 81 \\
\hline
\end{tabular}

From the results of the activities on the data above, it can be read that in the pre-cycle, cycle I, and cycle II an increase in value. This proves that through workshop activities can improve the ability to compose questions for grade VI elementary school teachers in Dabin III, Tambak District.

The teachers have ability to construct the test items properly because have a good understanding of the assessment techniques and test development procedures. Test items will have high quality if valid and reliable. They also have make good question and assess it. This is inline of Sujana and Arikunto statement, that the assessment is said to be good if the question has or meets two criteria, namely validity and reliability [7-8].

\section{CONCLUSION}

Through workshops, there is improvement in the competency of grade VI teachers to construct test items at Dabin III Tambak District, Banyumas Regency for the 2017/2018 academic year. It is shown by the results of the assessment carried out by comparing the acquisition of values from the initial conditions, cycle I to cycle II with an average value of 59 in pre-cycle, and increased to 69 in first cycle I and increasing again to 81 in second.

It is necessary to improve the competency of grade VI teachers to construct test items, to this end author addressed suggestions as follows:

1. Academic coaching and supervision should be consistently carried out by both the principal and the supervisor specifically in constructing test items.

2. The teacher in constructing test items for School quiz or exams should use the procedures that have been determined according to the guidelines for constructing test items.

3. It is necessary to activate The Teacher Working Group (KKG) for all teachers, in order to improve teachers competence. 


\section{REFERENCES}

[1] Himawan MS. The development of Indonesian teacher competence questionnaire. Journal of Educational, Health and Community Psychology. 2016;5(2):1-5..

[2] Rahardjo S. The effect of competence, leadership and work environment towards motivation and its impact on the performance of teacher of elementary school in Surakarta city, Central Java, Indonesia. International Journal of Advanced Research in Management and Social Sciences. 2014;3(6):59-74..

[3] Ginting H, Surya E. Development Learning Device Based for Measuring Contextual Critical Thinking Skills Students SD Class VI Mathematical. International Journal of Sciences: Basic and Applied Research (IJSBAR). 2017;33(3):301-10.

[4] Livingston K, Hutchinson C. Developing teachers' capacities in assessment through careerlong professional learning. Assessment in Education: Principles, Policy \& Practice. 2017 Apr 3;24(2):290-307.

[5] Daryanto \& Rachmawati T. Supervisi pembelajaran. Yogyakarta: Gava Media. 2015.

[6] Sudijono A. Pengantar Evaluasi Pendidikan. Jakarta: PT Raja Grafindo Persada. 2015.

[7] Sudjana N. Penilaian Hasil Proses Belajar Mengajar. Bandung: Rosda. 2016

[8] Suharsimi A. Penelitian Tindakan Kelas. Jakarta: Penerbit Bumi Aksara. 2015

[9] Sugiono. Metode Penelitian Pendidikan Bandung : Alfabeta. 2015.

[10] Uluyol Ç, Şahin S. Elementary school teachers' ICT use in the classroom and their motivators for using ICT. British Journal of Educational Technology. 2016 Jan;47(1):6575.

[11] Badarudin B. Peran Kepala Sekolah Dasar dalam Mempersiapkan Sumber Daya Pendidik Menghadapi Implementasi Kurikulum 2013. Dinamika Jurnal Ilmiah Pendidikan Dasar. 2019 Feb 12;10(2). 